\title{
Comparative Wood Anatomy of Atraphaxis taxa in Turkey
}

Funda Erşen Bak ${ }^{\mathrm{a}, *}$ and Derya Cesur ${ }^{\mathrm{b}}$

The wood anatomy of four Atraphaxis taxa that have natural distribution in Turkey-Atraphaxis billardieri Jaub. \& Spach, Atraphaxis billardieri subsp. tournefortii (Jaup. \& Spach) Lovelius, Atraphaxis spinosa L., and endemic Atraphaxis grandiflora (Willd.)-were compared in this study. The wood samples were sectioned according to standard techniques. Samples were macerated with Schultze's method. Tangential and radial vessel diameters, intervessel pit diameters, vessel wall thickness, vessel elements length, dimensions of libriform fibres (lengths, widths, cell wall thickness and, lumen diameter), and uniseriate and biseriate ray heights were measured, and the number of vessels per $\mathrm{mm}^{2}$, number of rays per $\mathrm{mm}$, and number of vessels per group were counted. The qualitative features such as growth rings, vessel grouping, presence of helical thickening and storied structure, vestured pits, type of perforation plate, and arrangement of axial parenchyma were determined. These four species of Atraphaxis shrubs differ in some wood characteristics such as growth rings, vessel grouping, vestured pits, height and density of rays, number of vessels per $\mathrm{mm}^{2}$, and the dimensions of the vessel.

Keywords: Wood Anatomy; Atraphaxis; Turkey

Contact information: a: Department of Forest Faculty, Artvin Çoruh University, Artvin, Turkey; b: Graduate School of Natural and Applied Sciences, Artvin Çoruh University, Artvin, Turkey;

* Corresponding author: fundaersenbak@artvin.edu.tr

\section{INTRODUCTION}

The genus Atraphaxis L. (Polygonaceae) comprises 36 woody species across Southern Europe, Northern Africa, and predominately Asia (Siberia, China, and Mongolia) (Schuster et al. 2011; Yurtseva et al. 2014; 2016; Tavakkoli et al. 2015). There have been many taxonomic studies (morphologic, palynology, and phylogenetic) on the genus (Pavlov 1970; Haraldson 1978; Ronse Decraene and Akeroyd 1988; Ronse Decraene et al. 2000; Sanchez et al. 2011; Schuster et al. 2011; Sun and Zhang 2012; Tavakkoli et al. 2015; Yurtseva et al. 2016). However, few studies have been reported on the wood anatomy of Atraphaxis genus (Jansen et al. 2001; Carlquist 2003; 2010). Jansen et al. (2001) has mentioned A. spinosa (from Turkey) briefly in their study that vestured pits were investigated, and their taxonomic and evolutionary significance was evaluated. Similarly, species of A. pungens (M. Bieb.) Jaub. \& Spach and A. frutescens (L.) Ewersm. were partially mentioned in studies where wood diversity of Polygonaceae (Carlquist 2003) was examined and Caryophyllales (Carlquist 2010) was evaluated in terms of ontogenetic, phylogenetic, and ecologic factors.

According to floral characteristics (the numbers of tepal, stamen, style, and achene type), the genus Atraphaxis is divided into two subgenera Euatraphaxis and Tragopyrum (Pavlov 1970) or two sections Atraphaxis and Tragopyrum (Rechinger and SchimanCzeika 1968). The genus Atraphaxis is represented by 5 species in Turkey, one of which 
is endemic (A. grandiflora Willd.). Four taxa (A. grandiflora Willd., A. angustifolia Jaub. \& Spach, A. billardieri Jaub. \& Spach, and A. billardieri Jaub. \& Spach subsp. tournefortii (Jaub. \& Spach) Lovelius) are indicated in the subgen. Tragopyrum, while one species ( $A$. spinosa L.) is categorized in the subgen. Atraphaxis (Cullen 1967). Although the only Turkish record is the type specimen, the presence of Atraphaxis angustifolia in Turkey is doubtful (Cullen 1967).

The goal of the present study is to describe and compare the anatomical characteristics of wood in Atraphaxis billardieri, A. billardieri subsp. tournefortii, A. grandiflora, and A. spinosa.

\section{EXPERIMENTAL}

\section{Materials}

All studied Atraphaxis taxa spread in arid areas and especially dry hillsides and rocky slopes. A. spinosa is an erect shrub up to $1 \mathrm{~m}, A$. grandiflora $(<30 \mathrm{~cm})$ and taxa of A. billardieri $(\leq 60 \mathrm{~cm})$ are low shrubs. All of them are deciduous. Plant samples were collected from natural habitats in Turkey (Table 1).

Table 1. The Collection Data of Studied Samples

\begin{tabular}{|l|l|l|}
\hline Taxon & Locality & Voucher Number \\
\hline Atraphaxis billardieri & $\begin{array}{l}\text { Antalya, Elmalı, Avlan Gölü, 1055m } \\
36^{\circ} 34^{\prime} 03^{\prime \prime} \mathrm{N}, 29^{\circ} 56^{\prime} 57^{\prime \prime} \mathrm{E}\end{array}$ & Erşen Bak 300 \\
\hline $\begin{array}{c}\text { Atraphaxis billardieri } \\
\text { subsp. tournefortii }\end{array}$ & $\begin{array}{c}\text { Artvin, 400 m } \\
41^{\circ} 12^{\prime} 33^{\prime \prime} \mathrm{N}, 42^{\circ} 02^{\prime} 03^{\prime \prime} \mathrm{E}\end{array}$ & Erşen Bak 301 \\
\hline Atraphaxis grandiflora & $\begin{array}{c}\text { Erzincan, Refahiye, 1750 m } \\
39^{\circ} 54^{\prime} 01^{\prime \prime} \mathrm{N}, 38^{\circ} 45^{\prime} 32^{\prime \prime} \mathrm{E}\end{array}$ & Erşen Bak 302 \\
\hline Atraphaxis spinosa & $\begin{array}{c}\text { Iğdır, Aralı, } 823 \mathrm{~m} \\
39^{\circ} 52^{\prime} 15^{\prime \prime} \mathrm{N}, 44^{\circ} 30^{\prime} 19^{\prime \prime} \mathrm{E}\end{array}$ & Erşen Bak \& Cesur 9 \\
\hline
\end{tabular}

\section{Methods}

Wood samples were obtained from the stem section and were boiled, and stored in equal amounts of ethanol, glycerin, and distilled water (Merev 1998). Wood materials were sectioned with a sliding microtome and cryostat. The sections were stained with safranine O and alcian blue (Ruzin 1999; Ives 2001). Macerations were prepared using Schultze's method (Normand 1972). On sections, tangential and radial vessel diameters, intervessel pit diameters, vessel wall thickness and, uniseriate and biseriate ray heights were measured, and the number of vessels per $\mathrm{mm}^{2}$, the number of rays per $\mathrm{mm}$, and the number of vessels per group were counted. The vessel elements length, libriform fibre dimensions (lengths and widths, the thickness of cell walls, lumen diameter) were measured on macerated specimens. The qualitative features such as growth rings, vessel grouping, presence of helical thickening and storied structure, vestured pits, type of perforation plate, and the arrangement of axial parenchyma were determined. Also, vulnerability ratio (vessel diameter/ numbers of vessels per $\mathrm{mm}^{2}$ ) and mesomorphy value (vulnerability ratio $\mathrm{x}$ vessel element length) were calculated by using vessel member characteristics (Carlquist 1977, 1988). The average value for each feature was based on 30 measurements and/or counts. Vessel diameter was measured on the basis of the lumen and was taken at the widest point. Vessel element length, including its tails, was obtained from macerations (Baas et al. 1983; 
Carlquist 1988). Measurements and microphotographs were taken with an Olympus BX 53 microscope with DP73 (Tokyo, Japan). Helical thickening and vestured pits were examined in detail using a Zeiss/Evo LS10 scanning electron microscope (Cambridge, UK). All wood terms used conform to the usage of the International Association of Wood Anatomists Committee on Nomenclature (IAWA Committee 1989).

\section{RESULTS AND DISCUSSION}

The wood anatomical properties of the Atraphaxis species are listed below. The mean values of selected quantitative data are listed in Table 2.

\section{Atraphaxis billardieri}

Wood ring porous, growth ring distinct (marked by thick-walled, radially flattened latewood fibres and vascular tracheids) (Fig. 1a). Vessels ca. 146 to $156 / \mathrm{mm}^{2}$, mostly solitary (63\%) and in usually tangential multiples of 2 to 3 (4 to 7), or in small radial groups or in small clusters (Fig. 1a), mean number of vessels per group 1.65 (2 to 7); rounded in cross-section, earlywood vessels tangential diameter 30 to $80 \mu \mathrm{m}$ and radial diameter 30 to $83 \mu \mathrm{m}$, latewood vessels tangential diameter 10 to $26 \mu \mathrm{m}$ and radial diameter 10 to $36 \mu \mathrm{m}$, walls 2.28 to $5.54 \mu \mathrm{m}$ in thickness. Narrow vessels intergrading with vascular tracheids in latewood. Vessel member length 125 to $202 \mu \mathrm{m}$. Perforations simple in horizontal to oblique end walls. Intervessel pits vestured (Fig. 2c), alternate, rounded or oval, 3.68 to $5.98 \mu \mathrm{m}$ in diameter, with slit-like or coalescent apertures. Earlywood $( \pm)$ and latewood (+) vessels with helical thickenings, vessel members storied. Axial parenchyma scanty paratracheal or vasicentric. Libriform fibres 314 to $491 \mu \mathrm{m}$ long, 10.31 to $21.36 \mu \mathrm{m}$ wide, thin- to thick-walls ( 2.52 to $5.29 \mu \mathrm{m})$, simple pits on radial and tangential walls. Rays 1 to $6 / \mathrm{mm}$, mostly uniseriate ( 45 to $230 \mu \mathrm{m}, 2$ to 9 cells high) and biseriate ( 80 to $195 \mu \mathrm{m}$ ), very rarely multiseriate ( 3 cells); heterocellular. Silica bodies were observed and darkstaining deposits in ray and axial parenchyma cells.

\section{Atraphaxis billardieri subsp. tournefortii}

Wood ring porous, growth ring distinct (marked by thick-walled, radially flattened latewood fibres and vascular tracheids) (Figs. 1b, 1e). Vessels ca. 108 to $168 / \mathrm{mm}^{2}$, solitary (44\%) and in usually tangential (predominantly at the beginning of growth ring) to radial multiples of 2 to 4 (8 to 10), or in small clusters (Fig. 1e), mean number of vessels per group 2.5 (2 to 10); rounded in cross-section, earlywood vessels tangential diameter 25 to $80 \mu \mathrm{m}$ and radial diameter 35 to $85 \mu \mathrm{m}$, latewood vessels tangential diameter 15 to $35 \mu \mathrm{m}$ and radial diameter 10 to $35 \mu \mathrm{m}$, walls 3.26 to $9.01 \mu \mathrm{m}$ in thickness. Narrow vessels intergrading with vascular tracheids in latewood. Vessel member length 115 to $195 \mu \mathrm{m}$. Perforations simple in horizontal to oblique end walls. Intervessel pits vestured (Fig. 2b), alternate, rounded or oval, 4.8 to $7.96 \mu \mathrm{m}$ in diameter, with slit-like or coalescent apertures. Earlywood ( \pm ) and latewood (+) vessels with helical thickenings, vessel members storied. Axial parenchyma scanty paratracheal or vasicentric. Libriform fibres 210 to $430 \mu \mathrm{m}$ long, 11.62 to $23.24 \mu \mathrm{m}$ wide, thin- to thick-walls $(2.49$ to $4.15 \mu \mathrm{m})$, simple pits on radial and tangential walls. Rays 1 to $5 / \mathrm{mm}$, mostly uniseriate ( 45 to $325 \mu \mathrm{m}, 2$ to 11 cells high) and biseriate (90 to $525 \mu \mathrm{m}$ ), very rarely multiseriate (3 cells); heterocellular. Silica bodies (Fig. 2j) and dark-staining deposits were observed in ray and axial parenchyma cells. 


\section{Atraphaxis grandiflora}

Growth rings distinct. Wood diffuse to semi-ring porous (Figs. 1c, 1f). Vessels $c a$. 140 to $181 / \mathrm{mm}^{2}$, in tangential and radial group of 2 to 4 , or in clusters (5 to 9), or solitary (48\%) (Fig. 1f), mean number of vessels per group 2.1 (2 to 9); rounded to angular in crosssection, earlywood vessels tangential diameter 28 to $70 \mu \mathrm{m}$ and radial diameter 29 to 70 $\mu \mathrm{m}$, latewood vessels tangential diameter 10 to $23 \mu \mathrm{m}$ and radial diameter 8 to $29 \mu \mathrm{m}$, walls 2.28 to $4.96 \mu \mathrm{m}$ in thickness. Vasicentric vascular tracheids present adjacent to in vessel grouping. Vessel member length 105 to $220 \mu \mathrm{m}$. Perforations simple in horizontal to oblique end walls. Intervessel pits vestured (Fig. 2a), alternate, rounded or oval, 3.84 to $7.03 \mu \mathrm{m}$ in diameter, with slit-like or coalescent apertures (Fig. 2f). Wide (rare and very slightly) and narrow (+) vessels with helical thickenings (Fig. 2f), vessel members storied (Fig. 2h). Axial parenchyma scanty paratracheal or vasicentric. Libriform fibres 275 to 550 $\mu \mathrm{m}$ long, 11.18 to $45.32 \mu \mathrm{m}$ wide, thin- to thick-walls $(2.12$ to $8.65 \mu \mathrm{m})$, simple pits on radial and tangential walls. Rays 1 to $5 / \mathrm{mm}$, uniseriate (40 to $325 \mu \mathrm{m}, 2$ to 10 cells high) and biseriate (130 to $430 \mu \mathrm{m}$ ), rarely multiseriate; heterocellular (Fig. 2i).

Table 2. Some Wood Anatomical Characteristics of Atraphaxis taxa

\begin{tabular}{|l|l|l|l|l|}
\hline Characteristics & A. billardieri & $\begin{array}{l}\text { A. billardieri } \\
\text { subsp. tournefortii }\end{array}$ & A. grandiflora & A. spinosa \\
\hline ETD & 52.28 & 45.83 & 41.49 & 53.23 \\
\hline ERD & 56.38 & 58.83 & 49.74 & 74.09 \\
\hline LTD & 18.34 & 20.65 & 15.44 & 19.50 \\
\hline LRD & 20.84 & 23.55 & 16.32 & 23.95 \\
\hline VF & 150 & 128 & 155 & 185 \\
\hline VG & 1.65 & 2.5 & 2.1 & 2.5 \\
\hline VEL & 155.93 & 159.50 & 156.50 & 109.08 \\
\hline LFL & 400.68 & 348.50 & 396.50 & 322.33 \\
\hline LFW & 15.61 & 17.18 & 22.10 & 14.82 \\
\hline UH & $115.31 / 4$ & $118.95 / 4$ & $130.11 / 4$ & $127.92 / 6$ \\
\hline BH & 129.25 & 178.67 & 191.47 & 282.01 \\
\hline U & 4 & 4 & 3 & 8 \\
\hline V & 0.23 & 0.26 & 0.18 & 0.20 \\
\hline ME & 36.71 & 41.42 & 28.74 & 21.44 \\
\hline
\end{tabular}

$\mathrm{ETD}=$ earlywood vessels tangential diameter, $\mu \mathrm{m} ; \mathrm{ERD}=$ earlywood vessels radial diameter, $\mu \mathrm{m}$; $\mathrm{LTD}=$ latewood vessels tangential diameter, $\mu \mathrm{m} ; \mathrm{LRD}=$ latewood vessels radial diameter, $\mu \mathrm{m} ; \mathrm{VF}=$ number of vessels per $\mathrm{mm}^{2} ; \mathrm{VG}=$ mean number of vessels per group; $\mathrm{VEL}=$ vessel element length, $\mu \mathrm{m}$; $\mathrm{LFL}=$ libriform fibre length, $\mu \mathrm{m}$; $\mathrm{LFW}=$ libriform fibre width, $\mu \mathrm{m} ; \mathrm{UH}=$ uniseriate ray height, $\mu \mathrm{m}$ / cell; $\mathrm{BH}=$ biseriate ray height, $\mu \mathrm{m} ; \mathrm{U}=$ number of rays $/ \mathrm{mm} ; \mathrm{V}=$ vulnerability ratio (mean tangential vessel diameter / number of vessels per $\mathrm{mm}^{2}$ ); $\mathrm{ME}=$ mesomophy value (vulnerability ratio $\times$ vessel element length).

\section{Atraphaxis spinosa}

Growth rings distinct. Wood diffuse to semi-ring porous (Figs 1d, 1g). Vessels ca. 165 to $229 / \mathrm{mm}^{2}$, in radial group of 2 to 4 (7 to 9), or in clusters, or solitary (42\%) (Fig. $1 \mathrm{~g}$ ), mean number of vessels per group 2.5 (2 to 9); rounded to angular in cross-section, vessels of two distinct diameter classes (Fig. 2g), earlywood vessels tangential diameter 32 to $87 \mu \mathrm{m}$ and radial diameter 42 to $115 \mu \mathrm{m}$, latewood vessels tangential diameter 10 to 37 $\mu \mathrm{m}$ and radial diameter 10 to $40 \mu \mathrm{m}$, walls 1.96 to $3.99 \mu \mathrm{m}$ thick. Vasicentric vascular tracheids present adjacent to in vessel grouping. Vessel member length 75 to $137 \mu \mathrm{m}$. 

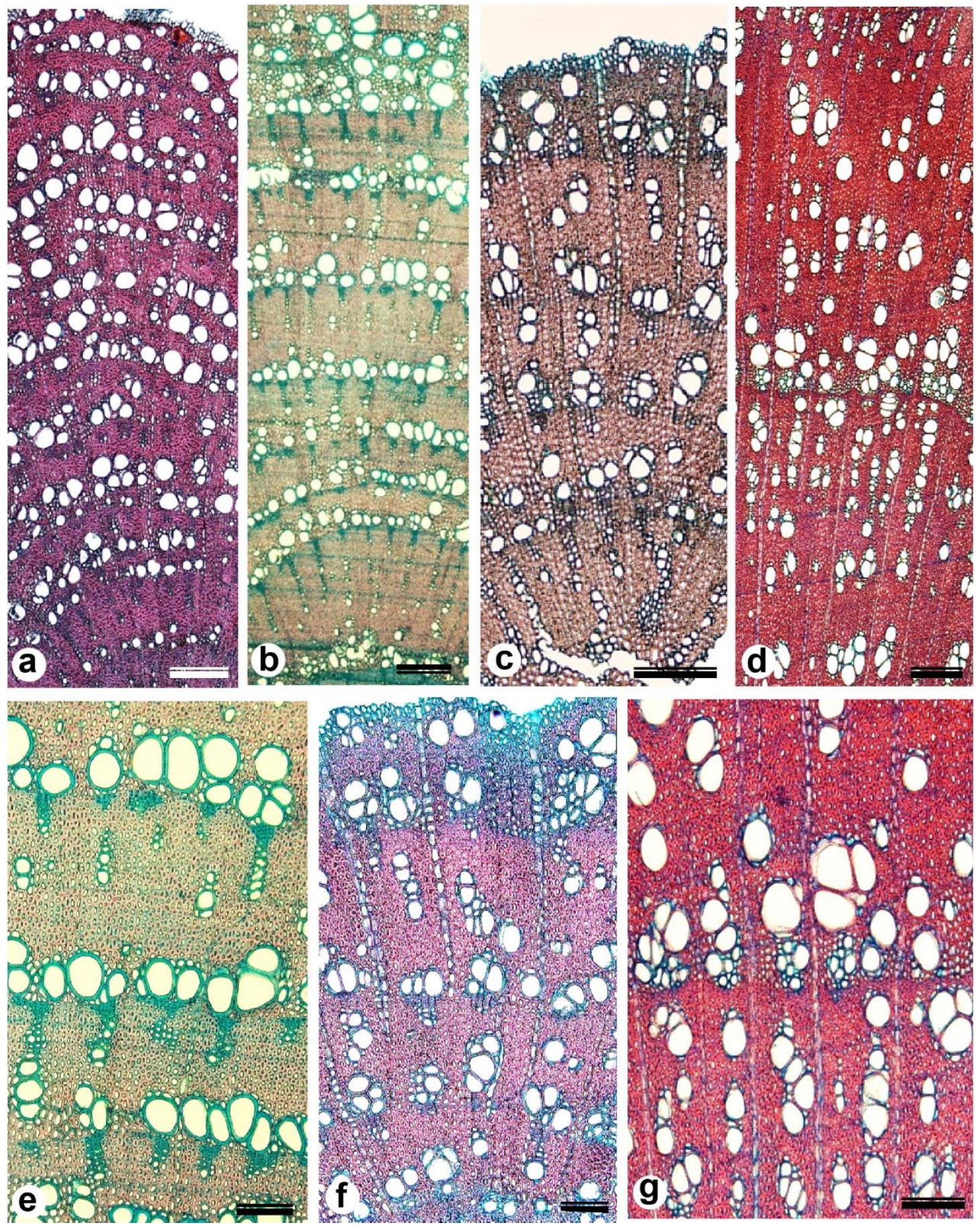

Fig. 1. Transverse sections. a: Atraphaxis billardieri, b, e: Atraphaxis billardieri subsp. tournefortii, c, f: Atraphaxis grandiflora, d, g: Atraphaxis spinosa. a, b: Wood ring porous and growth ring boundaries distinct, c, d: Wood diffuse to semi ring porous and growth ring boundaries distinct, e: Vessels in tangential to radial multiples or small clusters, scanty paratracheal or vasicentric axial parenchyma, f: Vessels in tangential and radial group, or in clusters, $\mathrm{g}$ : Vessels in radial multiples of 2 to 4 or in clusters, axial parenchyma scanty paratracheal or vasicentric. Scale bars $\mathrm{a}-\mathrm{C}=200$ $\mu \mathrm{m}, \mathrm{e}-\mathrm{g}=100 \mu \mathrm{m}$. 

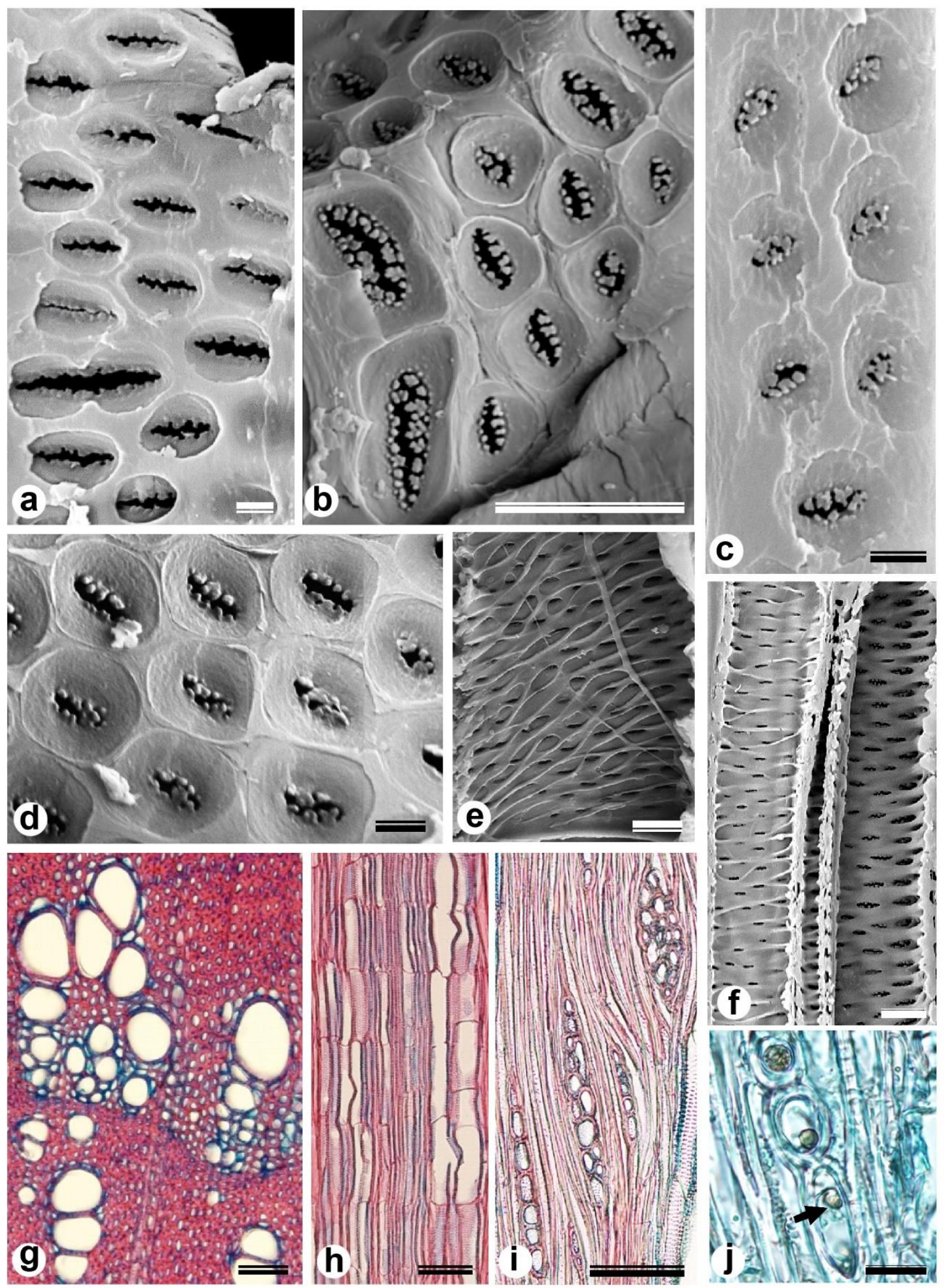

Fig. 2. Some qualitative characteristics. a, f, h: Atraphaxis grandiflora, b, I, j: Atraphaxis billardieri subsp. tournefortii, c: Atraphaxis billardieri, d, e, g: Atraphaxis spinosa. a-d: Vestured pits on vessel walls, e: Helical thickening in earlywood vessel elements, f: Helical thickening in vessel elements (left) and coalescent pit apertures (right), g: Two distinct vessel diameter classes in ring boundaries, h: Vessel elements storied, i: Heterocellular uniseriate, biseriate and multiseriate rays; j: silica bodies (arrow) in ray cells. Scale bars a, c, $d=2 \mu \mathrm{m} ; \mathrm{b}, \mathrm{e}, \mathrm{f}=10 \mu \mathrm{m} ; \mathrm{g}=50 \mu \mathrm{m} ; \mathrm{h}, \mathrm{i}=100 \mu \mathrm{m}$. 
Perforations simple in horizontal to oblique end walls. Intervessel pits vestured (Fig. 2d), alternate, rounded or oval, 4.99 to $6.23 \mu \mathrm{m}$ in diameter, with slit-like or coalescent apertures. Vessels with helical thickenings (Fig. 2e), vessel members storied. Axial parenchyma scanty paratracheal or vasicentric, and scanty marginal (1 to 2 seriate, initial). Libriform fibres 175 to $400 \mu \mathrm{m}$ long, 8.3 to $21.58 \mu \mathrm{m}$ wide, thin- to thick-walls ( 2.49 to $5.81 \mu \mathrm{m}$ ), simple pits on radial and tangential walls. Rays 5 to $11 / \mathrm{mm}$, uniseriate (58 to $225 \mu \mathrm{m}, 3$ to 13 cells high) and biseriate $(110$ to $470 \mu \mathrm{m}$ ), rarely multiseriate; heterocellular.

Although growth ring boundaries were distinct in all taxa, it was hard to distinguish latewood vessels in Atraphaxis spinosa. Narrow vessels and wide vessels were observed mixed in growth rings, especially in the growth ring initial. Vessel dimorphism, in which vessel diameter tends to be bimodal distribution (nearly), occurs in the Atraphaxis spinosa (Figs. 1d, 1g, 2g). Vines and xerophytes often have vessels of two distinct diameter classes (Baas and Schweingruber 1987; Carlquist 1988).

The mean numbers of vessels per group for these species are difficult to obtain because earlywood vessels can be solitary or in small groups, while very narrow latewood vessel groups (include vascular tracheids) can arrange wider patches. It is very difficult to distinguish between very narrow vessels and vascular tracheids in cross-section. Vascular tracheids occur at the end of the growth rings in all studied Atraphaxis taxa, and intergrading vessels (Figs. 1e, 1f). Carlquist $(1986$; 1988) reported vascular tracheids are formed at the end of the growth rings and do not tend to occur intermixed with vessels. In addition, Baas and Zhang (1986) and IAWA Committee (1989) reported they also formed around latewood vessel groups (in a vasisentric position). Because vascular tracheids that lack perforation plate are resistant to embolism, these cells protect the cambium during the dry season, in regions with water stress conditions at the end of the growing season. Vascular tracheids that provide safety to the conductive system are tend to be seen in drought-deciduous species.

A. spinosa has the shortest and the narrowest fibers among the studied taxa. There were shorter vessel elements and more numerous vessels in A. spinosa than the other Atraphaxis taxa (Table 2). According to Baas (1973), Baas et al. (1983), Baas and Carlquist (1985), and Wheeler and Baas (1991), vessel elements length and vessel diameter decrease from mesic vegetation towards xeric vegetation, and numbers of vessels in the unit area and vessels grouping rate increase. The calculated mesomorphy values are low for $A$. spinosa (21.44), A. grandiflora (28.74), A. billardieri (36.71), and A. billardieri subsp tournefortii (41.42). A mesomorphy value of less than 75 indicates xeromorphy (Carlquist 1977; 1988). A. spinosa has more xeromorphic characteristics compared to the others (Table 2). This species is spread in more arid fields. This value was calculated as 4.99 for A. pungens depending on vessel member features given in Carlquist (2003). Vessel dimorphism, vessel grouping, more numerous vessel, short vessel elements, and the presence of vascular tracheids are for safety against air embolism and provide increased safety rather than efficiency in the conductive system in drought taxa (Baas et al. 1983; Carlquist 1988)

While the diagnostic value of vestured pits is limited (Nair 1998; Jansen et al. 1998), they can be employed in wood identification (Bailey 1933; Ohtani and Ishida 1976; Merev 2003). The presence of vestured pits has been reported in Polygonaceae for some genera and species (Jansen et al. 1998, 2001; Carlquist 2003). Jansen et al. (2001) and Carlquist $(2003 ; 2010)$ detected vestured pits in A. spinosa (from Turkey), and A. pungens and $A$. frutescens, respectively. In the present study, vestured pits were photographed with 
SEM for A. spinosa, A. grandiflora, A. billardieri, and A. billardieri subsp. tournefortii (Figs. 2a to $2 \mathrm{~d}$ ). The vestured pits examined in this study not only differ among the studied taxa but also are different from the species examined in Carlquist's studies $(2003 ; 2010)$. Therefore, these findings emphasize the potential significance of vestured pits in the identification of Atraphaxis wood.

Carlquist (2003) stated that the width of multiseriate rays is two cells for most members of Polygonaceae. In this study, multiseriate rays $(\geq 3)$ are very rare. While biseriate rays are as common as uniseriate rays in $A$. spinosa, uniseriate rays are more common in A. billardieri, A. billardieri subsp. tournefortii, and A. grandiflora. The ray heights (uniseriate and biseriate) of A. spinosa and A. grandiflora are greater than subspecies of $A$. billardieri (Table 2). In A. spinosa and A. grandiflora, the mean height of uniseriate rays is 127.92 and 130.11 , respectively. In $A$. spinosa the mean height of biseriate rays was found to be longest among studied taxa. For Atraphaxis pungens, the mean height of uniseriate rays was 73, and the mean height of biseriate rays was 259 in Carlquist's study (2003). The number of rays per $\mathrm{mm}$ in A. spinosa more numerous than the other taxa. Ray frequency is more useful in wood identification than ray height because the latter varies depending on ontogeny (Carlquist 1988).

In earlier studies, storied narrow vessels and associated axial parenchyma strands were recorded for Calligonum arborescens, Antigonon leptopus, Dedeckera eurekensis, Eriogonum deserticola, E. heermannii, Gymnnopodium antigonoides, Polygonum lapathifolium (Carlquist 2003), and Calligonum polygonoides (Erşen Bak and Cesur 2020) in Polygonaceae. Carlquist (2003) has not reported a storied structure for Atraphaxis pungens, although this feature is relatively common in Polygonaceae. In this study, vessels are storied all studied Atraphaxis taxa, as shown for Atraphaxis grandiflora (Fig. 2h).

Helical thickenings in earlywood and/or latewood vessels are reported for Atraphaxis taxa (Figs. 2e, 2f). The presence of helical thickenings in vessels is reported for Eriogonum fasciculatum, E. giganteum (Carlquist and Hoekman 1985), Atraphaxis pungens, Bilderdykia multiflora, Eriogonum giganteum, $E$. heermannii, and Muehlenbeckia astonii (Carlquist 2003) in Polygonaceae. Grooves interconnecting (coalescent) pit apertures (Fig. 2f), which can be confused with helical thickening, were observed especially in earlywood or wide vessel walls of studied Atraphaxis woods. These grooves have been reported in vessels of Antigonon leptopus, Calligonum arborescens, Coccoloba laurifolia, Eriogonum fasciculatum, E. kennedyi, and Polygonum lapathifolium in Polygonaceae (Carlquist 2003).

\section{CONCLUSIONS}

1. These four species of Atraphaxis shrubs differ in some wood characteristics such as growth rings, vessel grouping, vestured pits, height and density of rays, number of vessels per $\mathrm{mm}^{2}$, and the dimensions of the vessel.

2. The properties such as vessel dimorphism, vessel grouping, vessel density, short vessel member, presence of helical thickening, and tracheids, which provide safety in the water conduction, are common in drought-deciduous species as Atraphaxis.

3. Vestured pits may be an important characteristic in identifying Atraphaxis wood. 


\section{ACKNOWLEDGEMENTS}

This study was financed by the Artvin Çoruh University Scientific Research Projects Unit with the project numbered as 2013.F10.01.02. The authors thank Dilek Öztekin and İbrahim Onkaş for assistance in obtaining the samples.

\section{REFERENCES CITED}

Baas, P. (1973). "The wood anatomical range Ilex (Aquifoliaceae) and its ecological and phylogenetic significance," Blumea 21, 193-258.

Baas, P., Werker, E., and Fahn, A. (1983). "Some ecological trends in vessel characters," IAWA Bulletin 4(2-3), 141-159.

Baas, P., and Carlquist, S. (1985). "A comparison of the ecological wood anatomy of the floras of Southern California and Israel," IAWA Bulletin 6 (4), 349-353.

Baas, P., and Zhang, X. (1986). "Wood anatomy of trees and shrubs from China I. Oleaceae," IAWA Bulletin 7(3), 195-220.

Baas, P., and Schweingruber, F. H. (1987). "Ecological trends in the wood anatomy of trees, shrubs and climbers from Europe," IAWA Bulletin 8(3), 245-274.

Bailey, I. W. (1933). "The cambium and its derivative tissue No.8. Structure, distribution and diagnostic significance of vestured pits in dicotyledons," Journal of the Arnold Arboretum 14, 259-273.

Carlquist, S. (1977). "Ecological factors in wood evolution: A floristic approach," American Journal of Botany 64 (7), 887-896.

Carlquist, S. (1986). "Terminology of imperforate tracheary elements," IAWA Bulletin 7(1), 75-81.

Carlquist, S. (1988). Comparative Wood Anatomy. Systematic, Ecological, and Evolutionary Aspects of Dicotyledon Wood ( $1^{\text {st }}$ Ed.), Springer-Verlag, Berlin, Germany.

Carlquist, S. (2003). "Wood anatomy of Polygonaceae: Analysis of a family with exceptional wood diversity," Botanical Journal of Linnean Society 141, 25-51.

Carlquist, S. (2010). "Caryophyllales: A key group for understanding wood anatomy character states and their evolution," Botanical J. of Linnean Society 164, 342-393.

Carlquist, S., Hoekman, D. A. (1985). "Ecological wood anatomy of the woody Southern Californian Flora," IAWA Bulletin 6, 319-341.

Cullen, J. (1967). "Atraphaxis," in: Flora of Turkey and the East Aegean Islands, P. H. Davis, (ed.), Edinburgh University Press, Edinburgh, UK, pp. 266-267.

Erşen Bak, F., and Cesur, D. (2020). "Wood anatomy of some dwarf halophyte shrubs in Turkey: Ecological implication," Fresenius Environmental Bulletin 29, 8834-8845.

Haraldson, K. (1978). "Anatomy and Taxonomy in Polygonaceae subfam: Polygonoideae Meisn. emend. Jaretzky," Acta Universitatis Upsaliensis, Symbolae Botanicae Upsalienses 22(2), 1- 95.

IAWA Committee, (1989). "IAWA list of microscopic features for hardwood identification," IAWA Bulletin 10(3), 221-332.

Ives, E. (2001). A guide to Wood Microtomy: Making Quality Micro Slides of Wood Sections, Suffolk Offset, Suffolk, UK. 
Jansen, S., Smets, E., and Baas, P. (1998). "Vestures in woody plants: A review," IAWA Journal 19(4), 347-382.

Jansen S., Smets, E., and Baas, P. (2001). "Vestured pits: Their occurrence and systematic importance in eudicots," Taxon 50 (1), 135-167.

Merev, N. (1998). Doğu Karadeniz Bölgesindeki Doğal Angiospermae Taksonlarının Odun Anatomisi 1. Cilt. KTÜ Matbaası, Trabzon, Turkey.

Merev, N. (2003). Odun Anatomisi, KTÜ Matbaası, Trabzon, Turkey.

Nair, M. N. B. (1998). Wood Anatomy and Major Uses of Wood, Faculty of Forestry, Universiti Putra Malaysia, Malaysia.

Normand, D. (1972). Manuel D'Identification des Bois Commerciaux. Tome 1, Généralités, Nogent- sur-Marne, Gerdat-Cıft, Paris.

Ohtani, J., and Ishida, S. (1976). "Study on the pits of wood cells using scanning electron microscopy. Report 5. Vestured pits in Japanese Dicotyledonous woods," Bulletins of the College Experiment Forests, College of Agriculture, Hokkaido Univ. 33, 407-435.

Pavlov, N. V. (1970). “Atraphaxis-Polygonaceae," in: Flora of the USSR 5, V.L. Komarov (ed.), English translation. Moscow \& Leningrad, pp. 392-411.

Rechinger, K. H., and Schiman-Czeika, H. (1968) "Polygonaceae," in: Flora Iranica, 56, K.H. Rechinger (ed), Akademische Druck- u.Verlagsanstalt, Graz, pp 36-46.

Ronse Decraene, L. P., and Akeroyd, J. R. (1988). "Generic limits in Polygonum and related genera (Polygonaceae) on the basis of floral characters," Botanical Journal of Linnean Society 98, 321-371.

Ronse Decraene, L. P., Hong, S. P., and Smets, E. F. (2000). "Systematic significance of fruit morphology and anatomy in tribes Persicarieae and Polygoneae (Polygonaceae)," Botanical Journal of Linnean Society 134, 301-337.

Ruzin, S. E. (1999). Plant Microtechnique and Microscopy, ( $1^{\text {st }}$ Ed.) Oxford University Press, Newyork.

Sanchez, A., Schuster, T. M., Burke, J. M., and Kron, K. A. (2011). "Taxonomy of Polygonoideae (Polygonaceae): A new tribal classification," Taxon 60, 151-160.

Schuster, T.M., Reveal, J.L., and Kron, K.A. (2011). "Phylogeny of Polygoneae (Polygonaceae: Polygonoideae)," Taxon 60, 1653-1666.

Sun, Y. X., and Zhang, M. L. (2012). "Molecular phylogeny of tribe Atraphaxideae (Polygonaceae) evidenced from five cpDNA genes," J. of Arid Land 4 (2), 180-190.

Tavakkoli, S., Kazempour Osaloo, S., Mozaffarian, V., and Maassoumi A. A. (2015). "Molecular phylogeny of Atraphaxis and the woody Polygonum species (Polygonaceae): Taxonomic implications based on molecular and morphological evidence," Plant Systematics and Evolution 301(4), 1157-1170.

Wheeler, E. A., and Baas, P. (1991). "A survey of the fossil record for Dicotyledonous wood and its significance for evolutionary and ecological wood anatomy," IAWA Bulletin 12(3), 275-318.

Yurtseva, O. V., Severova, E. E., and Bovina, I. Yu. (2014). "Pollen morphology and taxonomy of Atraphaxis (Polygoneae, Polygonaceae)," Plant Systematics and Evolution 300(4), 749-766. 
Yurtseva, O. V., Kuznetsova, O. I., Mavrodieva, M. E., and Mavrodiev, E. V. (2016). "What is Atraphaxis L. (Polygonaceae, Polygoneae): Cryptic taxa and resolved taxonomic complexity instead of the formal lumping and the lack of morphological synapomorphies," PeerJ 4, e1977.

Article submitted: October 13, 2020; Peer review completed: November 21, 2020;

Revised version received and accepted: December 4, 2020; Published: December 10, 2020.

DOI: $10.15376 /$ biores.16.1.835-845 